\title{
PENGEMBANGAN INSTRUMEN \\ PENILAIAN KINERJA GURU SEKOLAH DASAR \\ BERBASIS TUGAS POKOK DAN FUNGSI
}

\author{
Hesti Sadtyadi, Badrun Kartowagiran \\ STABN Raden Wijaya Wonogiri Jawa Tengah, Universitas Negeri Yogyakarta \\ 15hestisadtyadi@gmail.com, badrunkw@yahoo.com
}

\begin{abstract}
Abstrak
Tujuan penelitian ini adalah untuk mengembangkan instrumen penilaian kinerja guru sekolah dasar, dengan maksud diperolehnya komponen, indikator dan instrumen penilaian kinerja guru sekolah dasar. Instrumen penilaian kinerja guru sekolah dasar, dalam penelitian ini dikembangkan dengan metode research and development, berdasarkan model pengembangan pembelajaran Borg and Gall yang disesuaikan. Berdasarkan hasil analisis validitas dan reliabilitas, instrumen tersebut valid dan reliabel. Hasil analisis faktor menunjukkan fit model yang cukup baik, berarti dapat disimpulkan bahwa (1) instrumen penilaian kinerja guru sekolah dasar terdiri dari lima komponen yakni mengajar, mendidik, melatih dan mengarahkan, membimbing, serta menilai dan mengevaluasi, (2) masing-masing komponen instrumen penilaian kinerja guru dapat dijabarkan menjadi beberapa indikator relevan seperti yang dideskripsikan dalam hasil penelitian.
\end{abstract}

Kata kunci: instrumen penilaian kinerja, guru sekolah dasar

\section{THE ASESSMENT INSTRUMENT DEVELOPMENT OF ELEMENTARY SCHOOL TEACHERS' PERFORMANCE BASED ON TASKS AND FUNCTIONS}

\author{
Hesti Sadtyadi, Badrun Kartowagiran \\ STABN Raden Wijaya Wonogiri, Yogyakarta State University \\ 15hestisadtyadi@gmail.com, badrunkw@yahoo.com
}

\begin{abstract}
The objective of the research is to develop an assessment instrument of elementary school teachers' performance in order to attain the components, the indicators and the assessment instrument of the elementary school teachers' performance. The assessment instrument of elementary school teachers' performance, in the research, was developed by using research and development method that was adapted from the Borg and Gall's model of learning development. Based on the results of validity and reliability test, the instrument had been valid and reliable. The results of factor analysis show a quiet good fit model which leads to the following conclusions: (1) the assessment instrument of elementary school teachers' performance consists of five components namely: teaching, educating, training and directing, guiding and scoring and evaluating; and (2) each component for the assessment instrument of elementary school teachers' performance can be elaborated into several relevant indicators as described in the result of the study.
\end{abstract}

Keywords: instrument of performance assessment, elementary school teachers 


\section{Pendahuluan}

Guru mempunyai pengaruh yang paling penting terhadap kemajuan siswa, bahkan lebih penting daripada status sosial ekonomi dan lokasi sekolah (Suryadarma, Suryahadi, \& Sumarto, 2005, p.8). Guru merupakan kunci dalam sistem pendidikan, tetapi masih memiliki permasalahan terkait rendahnya kualitas pengajaran, kualitas pendidikan, maupun praktek pengajarannya. Masalah yang lainnya yaitu tidak adanya sistem pemantauan yang layak atau pengawasan yang efektif, terhadap aspek-aspek efektifitas dalam mengajar, maupun komponen lainnya. (Amin \& Khan, 2009). Keadaan ini mengindikasikan bahwa terdapat permasalahan dalam penilaian kinerja guru.

Berdasarkan data yang dikumpulkan peneliti berkaitan dengan penilaian kinerja guru sekolah dasar, dihasilkan bahwa instrumen yang digunakan dalam penilaian kinerja guru, belum berbasis pada hasil pelaksanaan tugas pokok dan fungsi guru, dalam mengajar, mendidik, melatih dan mengarahkan, membimbing serta menilai dan mengevaluasi. Instrumen yang digunakan dalam menilai kinerja guru cenderung terakumulasi dalam satu bagian, misalnya kinerja guru dalam pembelajaran. Instrumen tersebut merupakan akumulasi penilaian kinerja berdasarkan totalitas tugas pokok dan fungsi guru, yang tidak dispesifikasi berdasarkan komponen-komponen tugas pokok dan fungsi guru.

Sebagai gambaran, instrumen yang telah dikembangkan sebagai Alat Penilaian Kinerja atau Kemampuan Guru (APKG), memiliki komponen penilaian tugas guru dalam pembelajaran, dan hubungan antarpribadi (Supardi, 2013, p.71). Penilaian kinerja guru tersebut masih terakumulasi, secara global dalam pembelajaran. Komponen tugas guru sesuai dengan tugas pokok dan fungsinya belum tampak terbagi dalam substansi atau komponennya secara mandiri.

Berdasarkan survei yang dilakukan peneliti pada bulan Maret 2011 di Surakarta, memberikan gambaran pula bahwa instrumen penilaian yang dilakukan oleh pengawas meliputi penilaian terhadap pelaksanaan tugas guru dalam mengajar dan administrasinya. Melalui penilaian yang dilakukannya pada saat guru sedang mengajar, sulit untuk dapat menggambarkan kinerja guru yang sesungguhnya, karena guru memiliki kecenderungan lebih mempersiapkan diri, dibanding pada saat tidak dilakukan monitoring, dalam penilaian kinerjanya. Selain itu instrumen penilaian tersebut masih terbatas dalam substansi atau komponen tugas guru yang terbatas. Hal ini memberikan arti diperlukan bentuk penilaian dari instrumen yang mampu mengatasi permasalahan tersebut.

Berdasarkan tugas pokok dan fungsi guru sekolah dasar, yang relatif berbeda dengan guru yang lainnya menjelaskan bahwa, guru sekolah dasar khususnya guru kelas memiliki peran yang lebih komplek dibanding dengan guru pada jenjang pendidikan yang lainnya. Guru sekolah dasar memiliki kewajiban dalam membimbing siswa. Kompleknya tugas guru tersebut, berarti diperlukan instrumen yang dapat digunakan sebagai penilaian kinerja sesuai dengan tugas pokok dan fungsi gurunya.

Melalui berbagai jenis penilaian kinerja yang ada, hasilnya adalah guru masih belum mampu menunjukkan kinerja terbaiknya. Seperti disampaikan Sudarwan (2002, p.168), bahwa salah satu ciri krisis pendidikan di Indonesia adalah guru belum mampu menunjukkan kinerja (work performance) yang memadai. Salah satu yang menjadi sebab, karena penilaian kinerja guru terbatas dalam substansi tertentu saja, sehingga guru hanya mempersiapkan dan melakukan perbaikan berdasarkan substansi atau komponen tertentu. Keadaan ini sesuai dengan kondisi realita yang ada, bahwa instrumen penilaian kinerja guru masih bersifat terbatas dalam substansi tertentu, apalagi dalam substansi tersebut merupakan akumulasi beberapa komponen yang seharusnya dapat dinilai secara terpisah. Akibatnya guru dalam melakukan perbaikan kinerjanya terbatas dalam substansi yang terbatas pula. Hal ini menunjukkan bahwa diperlukan pengembangan instrumen penilaian kinerja guru sekolah dasar yang terjabarkan dalam faktor atau komponen tugas pokok dan fungsi guru.

Beberapa bentuk penilaian kinerja guru sekolah dasar menggunakan komponen dan indikator berdasarkan tugas pokok dan fungsi 
guru, seperti penelitian yang dilakukan Mohamad (2012), dengan mempergunakan komponen yang sesuai dengan kategori kinerja dari Peraturan Menteri Negara Pendayagunaan Aparatur Negara dan Reformasi Birokrasi Nomor 16 Tahun 2009. Penelitian yang dilakukan Wagiran (2010), dalam penelitian ini, kinerja guru diukur melalui hasil kerja guru, diantaranya melalui subkomponen tugas pokok dan fungsi guru yang dijabarkan dalam bidang tugas mengajar, mendidik, membimbing, dan melatih. Hal ini dapat digunakan dalam melihat kinerja berdasarkan komponennya.

Penelitian Anderson \& Brydges (2011), mempergunakan Professional Dispositions Assessment Rubric, dengan tujuh kriteria, yang dijabarkan dalam subkriteria sebagai standar guru dalam pembelajaran. Jabaran dari subkriteria tersebut jika dipilah dapat menjadi bagian dalam komponen tugas guru sekolah dasar. Tsang (2003) dalam penelitiannya mempergunakan rubrik untuk pengamatan dan untuk menilai kinerja guru baru dengan berbagai latar belakang. Komponen dalam penelitian ini mempergunakan komponen dan subkomponen tugas guru dalam pembelajaran, sehingga berdasarkan penilaiannya dapat dihasilkan penilaian kinerja berdasarkan komponennya.

Yamin dan Maisah (2010, p.140), mengatakan idealnya penilaian kinerja guru berdasarkan kinerja aktual yaitu berdasarkan komponen-komponen pokok melalui analisis pekerjaannya. Demikian halnya disampaikan Saud (2010, p.50) yang mengatakan bahwa kinerja profesi guru aktual, dalam penampilan proses belajar mengajar, minimal terdiri dari merencanakan, malaksanakan, menilai dan menguasai proses belajar mengajar.

Fredriksson, dalam Nuland, S. V. (2009, p.17) memberikan saran bahwa dalam mendefinisikan dimensi kualitas kerja guru, tidak seharusnya dilihat dari segi kemampuan dalam perilaku secara sempit, tetapi lebih dalam hal pekerjaanya. Kualitas guru harus dianggap sebagai sebuah konsep menyeluruh, yaitu sebagai kualitas yang menyeluruh, dan bukan hanya bagian dari perilaku terukur secara terpisah, yang berkembang secara mandiri dalam satu bagian. Terintegrasinya se- luruh kemampuan dari dimensi kualitas guru dapat menandai guru yang memiliki kinerja luar biasa. Guru dikatakan memiliki kualitas dalam kinerjanya jika memiliki kecakapan dalam mengajar, dalam melatih serta memiliki pengalaman. Guru dalam hal ini profesional dalam pekerjaanya. Pendapat tersebut lebih mempertegas bahwa dalam melihat kinerja guru tidak seharusnya hanya melalui salah satu komponen saja, tetapi seharusnya dilakukan dengan melihat secara menyeluruh komponen yang menjadi tugas guru yang tergabung dalam tugas pokok dan fungsi guru sebagai kinerja guru.

Dalam menjaga objektifitas penilaian, seharusnya dilengkapi dengan penilaian dari diri sendiri dan sejawat, dengan maksud, akan terjadi interaksi, bukan saja dalam hal nilainya, tetapi arah perubahan dan perbaikan kinerja yang diharapkan. Hasil penilaian kinerja seharusnya dapat digunakan sebagai mediasi dalam berkomunikasi antara penilai dengan yang dinilai. Melalui proses mengkomunikasikan hasil penilaian tersebut, dapat memberikan informasi terkait dengan hal-hal yang seharusnya dilakukan dan dipertahankan sebagai kinerja.

Pengembangan instrumen penilaian kinerja guru dengan sumber utama teman sejawat, dan diri sendiri, menjadi sangat penting. Bentuk self assesment dapat dipergunakan sebagai media penilaian diri. Asesmen teman sejawat, akan menjadi pelengkap sebagai komponen kritik atas kinerja tersebut. Rivai, et al (2011, p.55) mengatakan beberapa manfaat dari penilaian kinerja. Manfaat tersebut diantaranya adalah dapat meningkatkan motivasi kerja, juga meningkatkan kepuasan kerja. Melalui penilaian kinerja dapat diketahui kelemahan, dan kekuatan kinerjanya.

Penilaian kinerja juga dapat dipergunakan sebagai media dalam berkomunikasi di lingkungan kerja. Melalui pemahaman nilai pribadinya, dapat digunakan sebagai media berdiskusi dalam masalah pekerjaan, serta memperjelas kontek pekerjaan. Penilaian kinerja juga dapat memberikan kesempatan untuk mendiskusikan dan mendapatkan bimbingan dalam mencapai cita-cita yang diharapkan, maupun meningkatkan hubungan harmonis dalam pekerjaan. 
Penggunaan instrumen penilaian kinerja, dengan melibatkan langsung guru itu sendiri, dan teman sejawatnya akan lebih memperjelas tentang apa yang seharusnya guru lakukan, dan kekurangan yang dimiliki dalam pelaksanaan tugasnya. Seperti disampaikan oleh Dharma (2011, p.203), bahwa penilaian kinerja oleh diri sendiri banyak menghasilkan nilai yang realistis, selama dalam penilaian tersebut tidak mempengaruhi secara langsung upah atau gaji.

Mempergunakan penilaian diri memiliki kecenderungan seseorang lebih memahami atas pekerjaanya. Melalui penilaian diri sendiri, guru akan dapat mengetahui kelebihan dan kekurangan yang dimiliki, dan mampu melakukan perbaikan-perbaikan terhadap aspek-aspek yang dianggap kurang tepat. (Yamin \& Maisah, 2010, p.116). Komunikasi dengan atasan dapat ditingkatkan, serta memberikan dorongan untuk lebih berkembang. Penilaian oleh teman sejawat (peer assessment), juga memiliki keunggulan yakni lebih independen, selain bentuk penilaian ini cocok digunakan dalam struktur organisasi yang tidak hirarkis. Berk \& Hopkins, (2005), dalam hasil penelitian mengatakan bahwa penilaian teman sejawat dapat, memberikan gambaran yang sangat komprehensif dalam hal mengajar yang efektif dan dapat digunakan untuk perbaikan mengajar.

Saat ini bentuk instrumen penilaian kinerja melalui penilaian diri dan sejawat belum dikembangkan. Berarti diperlukan pengembangan instrumen penilaian kinerja guru untuk penilaian diri, penilai teman sejawat maupun penilaian atasan.

Pengembangan instrumen penilaian kinerja guru melalui penilaian diri sendiri, teman sejawat dan atasan, menjadi sangat dibutuhkan dalam rangka menghasilkan penilaian kinerja yang lebih komprehensif. Terlebih dengan mempergunakan tiap komponen yang merupakan tugas pokok dan fungsi guru sekolah dasar. Nilai penting dari pengembangan instrumen penilaian kinerja yang lebih komprehensif serta berdasarkan substansi pekerjaan guru, sangat berhubungan dengan keadaan dan kondisi yang diperlukan, seperti untuk perbaikan dalam mengajar maupun kebijakan atas pekerjaannya.
Tujuan penelitian ini adalah: (1). Menghasilkan instrumen penilaian kinerja guru sekolah dasar, yang lebih komprehensif dan berdasarkan tugas pokok dan fungsi guru sekolah dasar. (2) Mengetahui komponen yang dapat digunakan untuk menilai kinerja guru sekolah dasar. (3) Mengetahui indikator yang dibutuhkan dalam pelaksanaan tugas pokok dan fungsi guru sekolah dasar, yang terdiri dari komponen tugas mendidik, mengajar, melatih dan mengarahkan, membimbing, serta mengevaluasi.

Secara teoritis, dengan diketahuinya indikator tiap komponen dalam tugas pokok dan fungsi guru sekolah dasar, dan diketahuinya hubungan antara komponen (tugas pokok dan fungsi guru sekolah dasar) dan kinerja, dapat diketahui pula model struktural kinerja guru sekolah dasar, sehingga dapat disusun bentuk instrumen penilaian kinerja guru sekolah dasar. Instrumen penilaian kinerja guru sekolah dasar ini diharapkan dapat memberi sumbangan bagi perkembangan teori evaluasi atas kinerja guru, serta dalam manajemen pendidikan.

Secara praktis, hasil penelitian ini dapat memberi masukan kepada kepala sekolah, pengawas, guru, maupun pihak terkait tentang manfaat penggunaan instrumen kinerja guru sekolah dasar dan dampaknya terhadap peningkatan kinerja guru. Hasil penelitian ini dapat digunakan pula sebagai dasar dalam perbaikan dan meningkatkan kinerja guru sekolah dasar dalam mengelola tugasnya ke arah yang lebih efektif, serta dapat menjadi pertimbangan dalam mengambil kebijakan bagi pihak yang berwenang di bidang pendidikan.

\section{Metode}

Jenis Penelitian

Penelitian ini termasuk jenis penelitian dan pengembangan dalam bidang pendidikan, yang mempergunakan pengembangan dari model Borg \& Gall yang disesuaikan.

\section{Waktu Penelitian}

Prasurvei atau penelitian tahap awal dilakukan pada bulan Maret 2011. Focus Group Discussion dilakukan pada bulan Oktober 2012. Uji keterbacaan dilakukan pada bulan 
Desember 2012, dilanjutkan dengan uji tahap I atau operasional, pada bulan Desember 2012 sampai dengan Januari 2013. FGD dan Uji validasi isi kedua dilakukan pada Januari 2013. Uji tahap II atau implementasi dilakukan pada Pebruari - Maret 2013. Dapat dikatakan bahwa waktu penelitian adalah dimulai dari Maret 2011 sampai dengan Maret 2013.

\section{Subjek Penelitian}

Subjek penelitian adalah instrumen penilaian kinerja guru sekolah dasar. Objek penelitian ini adalah guru Sekolah Dasar Negeri yang ada di Kota Surakarta, yang dijadikan unit observasi (Observasional unit) atau dapat dikatakan sebagai subyek coba.

Data yang diperoleh dari guru, teman sejawat, dan kepala sekolah meliputi data kinerja guru dari pelaksanaan tugas pokok dan fungsi guru.

Tabel 1. Data Jumlah Subjek Uji coba

\begin{tabular}{ccccc}
\hline \multirow{2}{*}{$\begin{array}{c}\text { Tahap } \\
\text { uji }\end{array}$} & \multicolumn{4}{c}{ Jumlah } \\
\cline { 2 - 5 } & $\begin{array}{c}\text { Jumlah } \\
\text { SD }\end{array}$ & $\begin{array}{c}\text { Penilai } \\
\text { diri }\end{array}$ & $\begin{array}{c}\text { Penilai } \\
\text { Sejawat }\end{array}$ & Pimpinan \\
\hline I & 9 & 55 & 23 & 9 \\
II & 27 & 110 & 68 & 27 \\
\hline
\end{tabular}

Prosedur Pengembangan

Prosedur pengembangan dalam penelitian ini tidak meninggalkan sepuluh (10) rangkaian dari model Borg \& Gall (1983, p.772), yang disesuaikan. Sepuluh (10) tahap yang dikembangkan, yang jika disederhanakan menjadi tahapan berikut: (1) Tahap pendahuluan. Tahap ini merupakan tahap penelitian dan pengumpulan informasi terkait instrumen penilaian kinerja guru sekolah dasar. Dengan melakukan survei pendahuluan, melakukan kajian secara teoritis melalui teori dan peraturan perundangan yang berlaku bagi guru sekolah dasar. (2) Tahap perencanaan dan pengembangan produk awal. Tahap ini merupakan perencanaan instrumen penilaian kinerja guru sekolah dasar. Yang dimaksud pengembangan produk awal adalah kisi-kisi beserta instrumen berdasarkan perencanaan awal, sebelum dilakukan Focus Group Discussion, maupun uji keterbacaan serta validasi isi. Merupakan desain uji coba instrumen penilai- an kinerja guru sekolah dasar sebagai pengembangan bentuk produk awal. (3) Tahap uji coba, evaluasi dan revisi. Tahap ini merupakan tahap uji coba lapangan. Instrumen penilaian kinerja diterapkan dengan tujuan mengetahui sejauh mana instrumen penilaian kinerja guru tersebut dapat diterapkan dalam mengetahui kinerja guru sekolah dasar, yaitu melalui uji keterbacaan maupun Expert judgment/FGD I. Uji coba ini oleh Borg \& Gall disebut sebagai uji coba pendahuluan kemudian dievaluasi dan revisi, dan dilanjutkan dengan uji coba tahap I sebagai uji coba utama, atau operasional. Hasil uji tahap I dianalisis, dilanjutkan Expert jugment/FGD II, dan validasi II, kemudian dievaluasi dan revisi. (4). Tahap implementasi (Uji tahap II). Setelah instrumen dianggap reliabel, maka instrumen diterapkan pada kelompok guru sekolah dasar yang lain. Hasilnya merupakan sebuah instrumen penilaian kinerja guru sekolah dasar berdasarkan tugas pokok dan fungsi guru yang valid dan reliabel.

\section{Data, Instrumen, dan Teknik Pengumpulan Data}

Data dalam penelitian ini mencakup data kualitatif dan data kuantitatif. Jenis data yang dikumpulkan dalam diskusi, uji keterbacaan, FGD adalah data kualitatif. Sedangkan data yang dikumpulkan dalam uji coba instrumen adalah data kuantitatif.

Teknik dan instrumen pengumpulan data dalam penelitian pengembangan ini adalah instrumen yang berupa kajian teoritis dan pertanyaan-pertanyaan sebagai panduan pelaksanaa Focus Group Discussion, instrumen penilaian kinerja guru sekolah dasar yang dikembangkan berdasarkan kisi-kisi yang telah disusun, berupa instrumen penilaian diri, instrumen untuk penilaian teman sejawat, serta instrumen untuk penilaian atasan atau kepala sekolah. Selain instrumen identitas yang digunakan untuk penilaian diri, penilaian sejawat dan penilaian dari atasan.

\section{Teknik Analisis Data}

Hasil pengumpulan data dari FGD dianalisis dengan metode kualitatif, sedangkan data hasil pengembangan instrumen dianalisis secara kuantitatif. Berdasarkan alat yang digunakan maka analisis data mempergunakan 
analisis faktor, yang diawali dengan Exploratory factor analysis dengan kriteria $K M O \geq$ 0,5, dan ketentuan loading factor seperti dalam kriteria Exsploratory Factor Analysis (EFA). Analisis dilanjutkan dengan Second Order Confirmatory (2ndCF $A$ ), untuk model lengkap dan $C F A$ untuk model sederhanya. Metode ini digunakan untuk mendapatkan model serta faktor yang menyusun penilaian kinerja guru sekolah dasar. Pengujian atas kecocokan model teoritis dengan data empiris, model pengukuran dan instrumen didasarkan atas tiga indikator yaitu: (1) Chi Square, (2) Root Mean Square of Approximation (RMSEA), dan (3) Good Fit of Index (GFI). Kriteria yang digunakan untuk fit model adalah sebagai berikut jika Chi Square $\left(X^{2}\right) \leq 2 d f, p>0,05, \operatorname{RSME} A \leq$ 0,08. (Wijanto, 2007). Kriteria fit model yang memiliki pengertian serupa disampaikan pula oleh Basuki (2004), serta Ghozali, (2005), dengan kriteria untuk Chi Square $\left(X^{2}\right) \geq d f$, $p \leq$ 0,05 model fit, RMSE $A \leq 0,08$.

Untuk melihat apakah data memiliki perbedaan yang signifikan berdasarkan hasil penilaian yang dilakukan teman sejawat, kepala sekolah, dan diri sendiri guru digunakan Anova univariate analysis Anava) dengan mempergunakan program SPSS. Jika dengan mempergunakan $\alpha=0,05, \mathrm{~F}$ hitung $\geq \mathrm{F} \mathrm{Ta-}$ bel, berarti ada perbedaan penilaian yang dilakukan teman sejawat, kepala sekolah dan diri sendiri guru, begitu pula sebaliknya.

Penentuan batasan kriteria guru dengan kinerjanya mempergunakan pembagian berdasarkan skala Likert. Dalam pembagian dan klasifikasi kinerja guru, berdasarkan pelaksanaan tugas pokok dan fungsi maupun kinerja yang harus dimiliki mempergunakan kajian teori, pendapat ahli dan nilai aktual yang ada. Dari batasan dapat dirunut guru yang berkinerja sangat baik, berkinerja baik, berkinerja cukup, berkinerja kurang, maupun sangat kurang.

Validitas

Validitas isi bertujuan untuk mengkaji sejauh mana muatan/isi instrumen mewakili aspek yang dianggap kerangka konsep. Pengujian validasi isi instrumen penilaian kinerja guru sekolah dasar dilakukan melalui beberapa tahap yaitu melalui pendapat pakar dalam berbagai bidang, seperti pengukuran, pakar dibidang pendidikan dan pakar di bidang pendidikan sekolah dasar/psikologi, pakar bidang bahasa, maupun pakar bidang evaluasi. Validitas isi juga dilakukan dengan mempergunakan validasi isi Aikend's V. (Azwar, 2012, p.134).

Validitas konstrak, dilakukan dengan pendekatan Exploratory Factor Analysis. Kriteria yang dijadikan dasar untuk melihat valid tidaknya instrumen adalah: 1) butir yang memiliki muatan faktor $>0,5$, adalah butir yang akan dipertahankan sebagai butir yang valid Wijanto, (2007, p.193), Wibowo, (2004, p.3), dan Hair, et al (2006, p.129). 2) memiliki muatan faktor di atas 0,30, dipertimbangkan untuk dilakukan analisis dan revisi (Kim \& Muller, 1978, p.70), (Coakes \& Steed, 1996, p.124), (Azwar, 2010, p.64), dan (Hair, et al, 2006, p.129). 3). Apabila butir memiliki lebih dari satu muatan faktor di atas 0,30 yang mendekati sama, maka butir tersebut di gugurkan karena tidak berdimensi tunggal.

Validitas kontruk juga dilakukan dengan Second order confirmatory factor analysis (2nd$C F A$ ), untuk uji terhadap model konstruk penilaian kinerja dengan kompnen dan indikatornya, berdasarkan uji tahap II dan implementasi serta CFA (First order) (Ghozali, 2005, p.137), yang digunakan untuk melihat hubungan korelasi antarindikator dalam satu komponen, yang dapat memberikan saran perlu atau tidaknya indikator tersebut untuk digabungkan. Melalui 2ndCFA, akan dihasilkan nilai koefisien/parameter seperti koefisien $\lambda$ (lambda), signifikansi parameter berdasarkan hasil uji $\mathrm{t}$, yang menandakan $\mathrm{t}$ hitung $>\mathrm{t}$ tabel, berarti parameter tersebut signifikan. Signifikansi parameter tersebut menunjukkan bahwa instrumen tersebut valid. Besarnya koefisien parameter tersebut menunjukkan sebagai validitasnya.

\section{Reliabilitas}

Estimasi Reliabilitas instrumen penilaian kinerja guru sekolah dasar dilakukan dengan menggunakan pendekatan konsistensi internal dengan menggunakan formula Cronbach Alpha. Kriteria keterandalan instrumen adalah bila koefisien gabungan butir (reliabilitas alpha) 0,70 atau lebih maka instrumen 
tersebut dinyatakan handal (Nunnally, 1978, p.245). Reliabilitas juga menggunakan uji CFA, dengan memperhitungkan nilai koefisien $\delta$ (delta). Reliabilitas dihasilkan dari (1- $\delta$ ), yang menunjukkan sebagai reliabilitasnya. Dengan ketentuan nilai VE dan CR sebagai berikut, bahwa CR (Construct Reliability ) $\geq$ 0,7 , berarti reliabilitas model konstruk konvergen atau memiliki konsistensi internal, dan VE (Variance Extracted) $\geq 0,5$ berarti validitas model konstruk konvergen (Hair, 2006, p.779). Ketentuan tersebut menunjukkan bahwa reliabilitas model konstruk adalah baik. (Wijanto, 2007, p.148).

\section{Hasil Penelitian dan Pembahasan}

Penelitian diawali dengan penyusunan indikator melalui telaah teoritis dan telaah empirik. Telaah empirik dilakukan dengan menggunakan Foccus Group Discussion (FGD) I dan II yang digunakan sebagai validitas isi, dengan mencermati instrumen dari sisi bahasa, teknis penulisan, maupun kesesuaian kisikisi, baik indikator, maupun komponennya dengan instrumen penilaian kinerja guru tersebut, selain membandingkan dengan kajian teoritis. Melalui FGD ini dapat dihasilkan instrumen penilaian kinerja guru yang praktis, maupun sesuai dengan kajian teoritik.

Dalam Validasi praktisi tahap I, dihasilkan bahwa secara umum instrumen dapat dengan mudah dipahami, dan sesuai dengan pekerjaan yang dilakukan sebagai guru sekolah dasar. Validasi praktisi ini dilakukan dengan cara membahas tiap instrumen oleh guru, masukan atau bahasan dibandingkan de-ngan kisi-kisi instrumen, untuk dilihat kesesuaiannya. Validasi ini mempergunakan formula Aiken's V, yang ditujukan meng- hitung content-validity-coefficient, masing-masing instrumen dinilai oleh tiga guru sekolah dasar. Hasil uji dapat dikatakan bahwa semua instrumen memiliki nilai koefisien yang tinggi, dengan rata-rata yaitu 0,79 sampai dengan 0,81 , instrumen dapat dikatakan baik. Berarti instrumen tersebut layak digunakan dalam penilaian kinerja guru.

Validasi oleh pihak pengguna, merupakan kelanjutan dari FGD II, sebagai hasil validasi menghasilkan koefisien yang cukup tinggi, atau meningkat dibandingkan nilai koefisien validasi I. Rata-rata nilai content-validitycoefficient,adalah 0,87 sampai dengan 0,91 , yang menunjukkan bahwa instrumen tersebut layak untuk digunakan.

\section{Hasil Uji Coba Tahap I (Operasional)}

Gambaran yang dapat diberikan berdasarkan uji tahap I, yang dilakukan terhadap 9 sekolah dasar yang tersebar dalam 5 kecamatan di Surakarta, dengan jumlah sampel 55 orang guru sekolah dasar, dilakukan uji melalui Exploratory Factor Analysis.

Hasil uji tahap I melalui analisis faktor dengan pendekatan konfirmatori dengan exctraction method: maximum likelihood, menunjukkan instrumen tersebut valid dan reliabel. Nilai muatan faktor setiap butir dan indikator, memiliki nilai lebih dari 0,5, Terdapat 2 butir dengan faktor loding, kurang dari 0,5 (Tabel 4), yaitu Eva B1 (butir 45) dan Eva B2 (butir 46), yang merupakan bagian dari indikator tugas guru dalam melaksanakan evaluasi. Nilai tersebut masih dapat dipergunakan, dengan melakukan revisi tiap butir instrumen tersebut. Rangkuman data untuk exploratory factor analysis disajikan pada Tabel 2.

Tabel 2. Rangkuman Hasil Uji I terhadap Validitas (Exploratory factor analysis)

\begin{tabular}{ccccccc}
\hline & \multicolumn{6}{c}{ Rentang Nilai } \\
\cline { 2 - 8 } Komponen & \multicolumn{2}{c}{ Penilaina diri } & \multicolumn{2}{c}{ Penilaian sejawat } & \multicolumn{2}{c}{ Penilaian atasan } \\
\cline { 2 - 8 } & $\begin{array}{c}\text { Anti-image } \\
\text { Correlation } \\
\text { butir }\end{array}$ & $\begin{array}{c}\text { Rotated } \\
\text { Componen } \\
\text { Matrix }\end{array}$ & $\begin{array}{c}\text { Anti-image } \\
\text { Correlation } \\
\text { butir }\end{array}$ & $\begin{array}{c}\text { Rotated } \\
\text { Componen } \\
\text { Matrix }\end{array}$ & $\begin{array}{c}\text { Anti-image } \\
\text { Correlation } \\
\text { butir }\end{array}$ & $\begin{array}{c}\text { Anti-image } \\
\text { Correlation } \\
\text { butir }\end{array}$ \\
\hline 1 & 0,52 sd. 0,69 & 0,85 sd. 0,97 & 0,51 sd. 0,74 & 0,88 sd. 0,95 & 0,50 sd. 0,81 & 0,84 sd. 0,96 \\
2 & 0,46 sd. 0,69 & 0,82 sd. 0,93 & 0,44 sd. 0,68 & 0,84 sd. 0,93 & 0,47 sd. 0,76 & 0,84 sd. 0,92 \\
3 & 0,45 sd. 0,65 & 0,71 sd. 0,93 & 0,48 sd. 0,73 & 0,73 sd. 0,90 & 0,43 sd. 0,64 & 0,68 sd. 0,93 \\
4 & 0,41 sd, 0,66 & 0,71 sd. 0,91 & 0,42 sd. 0,65 & 0,67 sd. 0,9 & 0,36 sd. 0,63 & 0,64 sd. 0,90 \\
5 & 0,32 sd. 0,50 & 0,35 sd 0,94 & 0,31 sd. 0,53 & 0,54 sd. 0,88 & 0,31 sd. 0,58 & 0,50 sd. 0,94 \\
\hline
\end{tabular}


Nilai rotated componen matric yang lebih besar dari 0,5 menunjukkan bahwa instrumen tersebut membentuk faktor-faktor tertentu, seperti komponen tugas guru dalam mengajar, guru dalam mendidik, guru dalam melatih dan mengarahkan, guru dalam membimbing serta guru dalam menilai dan mengevaluasi. KMO yang dihasilkan lebih dari 0,5, yang menunjukkan KMO disebut miserable, berarti analisis dapat dilanjutkan. Nilai Cronbach's Alpha $>0,7$, menunjukkan bahwa instrumen tersebut reliabel. Rangkuman hasil perhitungan dalam Tabel 3 .
Tabel 3. Rangkuman Uji I Analisis Faktor dengan Exploratori

\begin{tabular}{|c|c|}
\hline Instrumen & Keterangan \\
\hline Penilaian diri & $\begin{array}{l}\text { KMO }=0,543 \\
\text { Cronbach's Alpha }=0,885\end{array}$ \\
\hline Penilaian Sejawat & $\begin{array}{l}\mathrm{KMO}=0,552 \\
\text { Cronbach's Alpha }=0,884\end{array}$ \\
\hline Penilaian atasan & $\begin{array}{l}\text { KMO }=0,529 \\
\text { Cronbach's Alpha }=0,887\end{array}$ \\
\hline $\begin{array}{l}\text { Simpulan } \\
\text { Reliabilitas }\end{array}$ & $\begin{array}{l}\text { Ketiga intrumen membentuk } \\
15 \text { Komponen, dan ke } 50 \text { butir } \\
\text { instrumen valid dan reliabel }\end{array}$ \\
\hline
\end{tabular}

Tabel 4. Rangkuman Hasil Uji I Terhadap Validitas (confirmatory factor analysis)

\begin{tabular}{|c|c|c|c|c|c|}
\hline \multirow{3}{*}{ Komponen } & \multicolumn{4}{|c|}{ Rentang nilai loading butir instrumen } & \multirow{3}{*}{ Simpulan } \\
\hline & diri & sejawat & atasan & Ket. & \\
\hline & $\lambda$ & $\lambda$ & $\lambda$ & t bitung $\lambda$ (lambda) & \\
\hline 1 & 0,88 sd. 0,99 & 0,91 sd. 1,00 & 0,87 sd. 1,00 & $\mathrm{t}$ hitung $>\mathrm{t}$ tabel & \multirow{5}{*}{$\begin{array}{c}\text { Tiap butir } \\
\text { instrumen valid }\end{array}$} \\
\hline 2 & 0,74 sd. 1,00 & 0,84 sd. 0,97 & 0,73 sd. 0,97 & $\mathrm{t}$ hitung $>\mathrm{t}$ tabel & \\
\hline 3 & 0,75 sd. 0,98 & 0,74 sd. 0,98 & 0,74 sd. 0,98 & $\mathrm{t}$ hitung $>\mathrm{t}$ tabel & \\
\hline 4 & 0,63 sd. 0,93 & 0,61 sd. 0,95 & 0,65 sd. 0,93 & $\mathrm{t}$ hitung $>\mathrm{t}$ tabel & \\
\hline 5 & 0,44 sd. 1,01 & 0,42 sd. 1,01 & 0,42 sd. 1,01 & $\mathrm{t}$ hitung $>\mathrm{t}$ tabel & \\
\hline
\end{tabular}

Berdasarkan confirmatory faktor analysis dalam Tabel 4 , dihasilkan simpulan yang sama, bahwa tiap instrumen tersebut valid dan reliabel. Validitas tiap butir dapat ditunjukkan dari nilai t hitung untuk nilai $\lambda$ (lambda), yang merupakan nilai koefisien yang menghubungkan masing-masing variabel manifes dengan variabel laten (variabel konstruk) lebih besar dari $\mathrm{t}$ tabel, yang berarti butir instrumen tersebut signifikan t tabel; $\alpha=0,05, \mathrm{dk} 60$, adalah 1,671, selain dalam uji model tersebut menghasilkan model yang fit. Hal ini berlaku untuk instrumen penilaian diri, penilaian sejawat dan penilaian atasan.

Berdasarkan hasil olahan data, dengan memperhatikan besaran parameter $\delta$ (delta) dengan menggunakan besaran $(1-\delta)$ atau merupakan $\mathrm{R}^{2}$ sebagai reliabilitasnya (Ghozali, 2008, p.137), (Basuki,2004, p.11), dihasilkan butir instrumen yang reliabel. Berdasarkan analisis terhadap nilai $C R$ (Construct Reliability), dan VR (Variance extracted) Tabel 5, dihasilkan nilai $C R \geq 0,70$, dan $V E \geq 0,50$, yang berarti baik (Wijanto, 2007, p.147). Sehingga konstruk dari tiap komponen tersebut memiliki reliabilitas yang baik.
Berdasarkan nilai korelasi antarindikator dalam tiap komponen tugas guru memiliki nilai korelasi antarindikator yang cukup rendah. Hal ini menunjukkan bahwa tiap indikator hanya mengukur satu indikator saja, hal ini bersesuaian dengan nilai loading faktor yang dihasilkan, yang menunjukkan bahwa tiap butir instrumen tersebut hanya mengukur butir intrumen dalam komponen tersebut. Nilai loading faktor tampak dalam rangkuman perhitungan uji validitas Tabel 5.

Tabel 5. Reliabilitas Konstruk, dan Variance Extracted Uji Tahap I

\begin{tabular}{|c|c|c|c|c|}
\hline \multicolumn{4}{|c|}{ Penilaian } & \multirow{2}{*}{ Ket. } \\
\hline Komponen & Diri & Sejawat & Atasan & \\
\hline$C R$ & 0,992 & 0,994 & 0,991 & \multirow{10}{*}{$\begin{array}{l}C R \geq 0,70, \\
V E \geq 0,50 \\
\quad=\text { Baik }\end{array}$} \\
\hline$V E$ & 0,913 & 0,927 & 0,906 & \\
\hline$C R$ & 0,975 & 0,974 & 0,977 & \\
\hline$V E$ & 0,779 & 0,777 & 0,797 & \\
\hline$C R$ & 0,974 & 0,972 & 0,972 & \\
\hline$V E$ & 0,805 & 0,795 & 0,797 & \\
\hline$C R$ & 0,963 & 0,965 & 0,963 & \\
\hline$V E$ & 0,744 & 0,758 & 0,744 & \\
\hline$C R$ & 0,924 & 0,918 & 0,919 & \\
\hline$V E$ & 0,589 & 0,571 & 0,573 & \\
\hline Ket & Sesuai & Sesuai & Sesuai & \\
\hline Simpulan & \multicolumn{2}{|c|}{ Reliabilitas Baik } & & \\
\hline
\end{tabular}


Keterangan:

komponen 1 : mengajar,

komponen 2 : mendidik,

komponen 3 : melatih dan mengarahkan,

kpmponen 4 : membimbing, dan

komponen 5 : menilai dan mengevaluasi.

\section{Hasil Uji Coba Tahap II (Implementasi)}

Uji coba instrumen penilaian kinerja guru, pada uji tahap II dilaksanakan di 27 sekolah dasar di kota Surakarta dengan jumlah sampel 110 orang guru. Data yang diperoleh memiliki distribusi normal, sehingga analisis dapat dilakukan dengan mempergunakan Exploratory Factor Analysis (EFA), yang dalam pe- nelitian ini dilakukan sebelum di analisis mempergunakan Confirmatory Faktor Analysis. Melalui EFA dihasilkan nilai KMO dengan kisaran $0,7 \leq \mathrm{KMO}<0,8$. Nilai tersebut dapat disebut middling, dan nilai faktor loading untuk tiap butir lebih dari 0,5 , yang menunjukkan bahwa butir tersebut valid. Nilai Rotated Componen Matrix, dalam uji tahap II menghasilkan 14 indikator, dan tiap butir hanya mengukur satu indikator, hal ini dapat dilihat dari nilai tiap anti image yang memiliki nilai lebih dari 0,5 . Tiap butir tidak ada yang memiliki dimensi ganda. Hasil perhitungan disajikan pada Tabel 6.

Tabel 6. Rangkuman Hasil Uji Analisis Faktor dengan Exploratori

\begin{tabular}{ccccccc} 
& \multicolumn{5}{c}{ Rentang Nilai } \\
\cline { 2 - 7 } Komponen & \multicolumn{2}{c}{ Penilaian diri } & \multicolumn{2}{c}{ Penilaian sejawat } & \multicolumn{2}{c}{ Penilaian atasan } \\
\cline { 2 - 8 } & $\begin{array}{c}\text { Anti-image } \\
\text { Correlation } \\
\text { butir }\end{array}$ & $\begin{array}{c}\text { Rotated } \\
\text { Componen } \\
\text { Matrix }\end{array}$ & $\begin{array}{c}\text { Anti-image } \\
\text { Correlation } \\
\text { butir }\end{array}$ & $\begin{array}{c}\text { Rotated } \\
\text { Componen } \\
\text { Matrix }\end{array}$ & $\begin{array}{c}\text { Anti-image } \\
\text { Correlation } \\
\text { butir }\end{array}$ & $\begin{array}{c}\text { Rotated } \\
\text { Componen } \\
\text { Matrix }\end{array}$ \\
\hline 1 & 0,68 sd. 0,88 & 0,68 sd. 0,88 & 0,61 sd. 0,88 & 0,58 sd. 0,85 & 0,77 sd. 0,87 & 0,76 sd. 0,92 \\
2 & 0,64 sd. 0,88 & 0,82 sd. 0,95 & 0,69 sd. 0,89 & 0,83 sd. 0,93 & 0,67 sd. 0,91 & 0,84 sd. 0,96 \\
3 & 0,75 sd. 0,85 & 0,81 sd. 0,91 & 0,72 sd. 0,86 & 0,83 sd. 0,92 & 0,73 sd. 0,82 & 0,80 sd. 0,91 \\
4 & 0,65 sd. 0,85 & 0,74 sd. 0,91 & 0,69 sd. 0,89 & 0,76 sd. 0,93 & 0,70 sd. 0,82 & 0,71 sd. 0,92 \\
5 & 0,79 sd. 8,7 & 0,65 sd. 0,87 & 0,72 sd. 0,89 & 0,63 sd. 0,92 & 0,72 sd. 0,88 & 0,61 sd. 0,91 \\
\hline
\end{tabular}

Berdasarkan Cronbach's Alpha $=0,940$, untuk instrumen penilaian diri, menunjukkan bahwa reliabilitas instrumen tersebut minimum dapat ditolerir, dan mendekati standar ideal. Demikian juga secara berurutan untuk instrumen penilaian sejawat dan penilaian atasan, memiliki Cronbach's $A \not p h a=0,935$, dan 0,940, hal ini menunjukkan bahwa instrumen tersebut reliabel. Berdasarkan nilai KMO yang lebih besar dari 0,5, baik instrumen penilaian diri, penilaian sejawat dan penilaian atasan yaitu sebesar 0,798, 0,781, dan 0,794, berarti hasil olahan data dapat digunakan untuk analisis. Nilai KMO dengan kisaran 0,7 $\leq \mathrm{KMO}<0,8$ tersebut dapat disebut middling. Hasil olahan data dalam Tabel 7.

Menggunakan Confirmatory Factor Analysis, melalui uji model $C F A$, dihasilkan nilai yang menunjukkan bahwa tiap komponen tugas guru, memiliki nilai fit model yang cukup baik, atau memenuhi kriteria indikator fit model. Nilai indikator untuk P-Value, Chi Square $\left(X^{2}\right)>0,05$ berarti model fit, untuk
RMSE $A \leq 0,05$ menandakan model fit, 0,05 $<$ RMSE $A \leq 0,08$ menunjukkan model reasonable, $0,08<\mathrm{RMSE} A \leq 0,1$, model fit yang cukup atau (mediocre), serta Nilai GFI $\geq$ 0,9 merupakan model fit. (Tabel 11 dan Gambar 1, 2 dan 3 ).

Tabel 7. Rangkuman Uji II Analisis Faktor dengan Exploratori

\begin{tabular}{ll}
\hline Instrumen: & Keterangan \\
\hline Penilaian & KMO =0,798, \\
diri & Cronbach's Alpha $=0,940$ \\
$\begin{array}{l}\text { Penilaian } \\
\text { Sejawat }\end{array}$ & KMO $=0,781$, \\
Penilaian & KMO $=0,794$, \\
atasan & Cronbach's Alpha $=0,940$ \\
\hline $\begin{array}{l}\text { Simpulan } \\
\text { Reliabilitas }\end{array}$ & $\begin{array}{l}\text { Ketiga instrumen membentuk } 14 \\
\text { faktor, ke 50 butir intrumen valid } \\
\text { dan reliabel. }\end{array}$ \\
\hline
\end{tabular}

Berdasarkan nilai loading factor untuk tiap butir, maupun tiap indikator, dalam instrumen penilaian diri, sejawat dan atasan, seperti terangkum dalam Tabel 8, yang diha- 
silkan nilai lebih besar dari 0,5, sehingga dapat dikatakan bahwa tiap butir dan indikator tersebut valid mengukur apa yang seharusnya diukur, demikian pula berdasarkan uji $\mathrm{t}$, yang menghasilkan $\mathrm{t}$ hitung $>\mathrm{t}$ tabel, untuk seluruh koefisien $\lambda$ (lambda,), menunjukkan bahwa instrumen penilaian kinerja guru sekolah dasar untuk semua komponen tugas guru dihasilkan instrumen yang valid. Artinya tiap butir instrumen tersebut valid.

Berdasarkan uji t koefisien $\delta$, dihasilkan nilai t hitung $>\mathrm{t}$ tabel, artinya koefisien $\delta$, signifikan. Besaran nilai (1- $\delta)$, menunjukkan besaran reliabilitas. Hal ini berarti seluruh butir instrumen tersebut reliable, demikian halnya nilai $C R$ (Construct Reliability) $\geq 0,7$, artinya reliabilitas model konstruk konvergen atau memiliki konsistensi internal, dan VE (Variance Extracted) $\geq 0,5$ Nilai $V E$ dan $C R$, dalam Tabel 9, menunjukkan bahwa model konstruk memiliki reliabilitas yang baik.

Tabel 8. Rangkuman Hasil Uji Validitas Tahap II (confirmatory factor analysis)

\begin{tabular}{|c|c|c|c|c|}
\hline \multirow{3}{*}{ 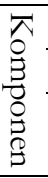 } & \multicolumn{4}{|c|}{ Rentang nilai loading butir instrumen } \\
\hline & diri & sejawat & atasan & Ket. \\
\hline & $\lambda$ & $\lambda$ & $\lambda$ & $\begin{array}{l}t \text { bitung } \lambda \\
\text { (lambda) }\end{array}$ \\
\hline 1 & 0,79 sd. 0,95 & 0,69 sd. 0,91 & 0,85 sd. 0,96 & $\begin{array}{l}t \text { hitung } \\
>t \text { tabel }\end{array}$ \\
\hline 2 & 0,85 sd. 0,97 & 0,88 sd. 0,98 & 0,85 sd. 0,99 & $\begin{array}{l}\mathrm{t} \text { hitung } \\
>\mathrm{t} \text { tabel }\end{array}$ \\
\hline 3 & 0,90 sd. 0,98 & 0,93 sd. 0,99 & 0,89 sd. 0,98 & $\begin{array}{l}t \text { hitung } \\
>t \text { tabel }\end{array}$ \\
\hline 4 & 0,82 sd. 0,97 & 0,86 sd. 0,98 & 0,84 sd. 0,97 & $\begin{array}{l}t \text { hitung } \\
>t \text { tabel }\end{array}$ \\
\hline 5 & 0,72 sd. 0,96 & 0,69 sd. 0,98 & 0,70 sd. 0,98 & $\begin{array}{l}t \text { hitung } \\
>t \text { tabel }\end{array}$ \\
\hline
\end{tabular}

Keterangan:

komponen 1 : mengajar,

komponen 2 : mendidik,

komponen 3 : melatih dan mengarahkan,

komponen 4 : membimbing, dan

komponen 5 : menilai dan mengevaluasi.

Analisis $2 n d C F A$ instrumen penilaian kinerja guru penilaian diri, sejawat dan atasan, menghasilkan nilai fit model yang baik dapat dilihat dari model konstruk tersebut, tampak dalam Tabel 11, Gambar 1,2 dan 3. Nilai loading faktor yang signifikan, $\mathrm{t}$ hitung $>\mathrm{t}$ tabel, serta nilai loading lebih besar dari 0,5, didukung dengan $V E \geq 0,5$ dan $C R \geq 0,7$, baik dari indikator ke komponen tugas guru, maupun dari komponen tugas guru terhadap kinerja guru (Tabel 8 dan 9), sehingga dapat dijelaskan bahwa instrumen penilaian kinerja guru tersebut dapat disusun dari komponen pelaksanaan tugas dan fungsi guru yang terdiri dari komponen tugas guru dalam mengajar, yang dapat disusun dari tiga indikatornya, meliputi 1) membuat rencana program mengajar, 2) melaksanakan program pembelajaran, 3) melaksanakan tindak lanjut program pembelajaran. Komponen tugas guru dalam mendidik yang dapat disusun dari tiga indikatornya, meliputi 1) mengembangkan potensi peserta didik, 2) mengembangkan kepribadian peserta didik, 3) melaksanakan penyesuaian penyelengaraan mendidik. Komponen tugas guru dalam melatih dan mengarahkan dapat disusun dari ke tiga indikatornya, yaitu 1) memberikan motivasi belajar, 2) memberikan panduan dalam belajar, dan 3) membiasakan berperilaku positif. Komponen tugas guru dalam membimbing, dapat disusun dari tiga indikatornya, yaitu 1) membuat rencana program bimbingan, 2) melaksanakan program bimbingan, dan 3) melaksanakan tindak lanjut program bimbingan. serta menilai dan mengevaluasi, yang dapat disusun dari dua indikatornya, yaitu 1) menyusun rencana evaluasi, serta 2) melaksanakan dan memanfaatakan hasil evaluasi.

Tabel 9. Rangkuman Reliabilitas Konstruk, dan V ariance Extracted Uji Tahap II

\begin{tabular}{|c|c|c|c|c|c|}
\hline \multicolumn{5}{|c|}{ Penilaian } & \multirow{2}{*}{ Ket } \\
\hline Kon & & Diri & Sejawat & Atasan & \\
\hline \multirow{2}{*}{1} & $C R$ & 0,975 & 0,961 & 0,984 & \multirow{10}{*}{$\begin{array}{l}C R \geq 0,70, \\
V \mathrm{E} \geq 0,50 \\
=\text { Baik }\end{array}$} \\
\hline & $V E$ & 0,769 & 0,673 & 0,834 & \\
\hline \multirow{2}{*}{2} & $C R$ & 0,986 & 0,987 & 0,987 & \\
\hline & $V E$ & 0,865 & 0,872 & 0,876 & \\
\hline \multirow{2}{*}{3} & $C R$ & 0,988 & 0,99 & 0,988 & \\
\hline & $V E$ & 0,904 & 0,915 & 0,904 & \\
\hline \multirow{2}{*}{4} & $C R$ & 0,977 & 0,983 & 0,98 & \\
\hline & $V E$ & 0,826 & 0,864 & 0,847 & \\
\hline \multirow{2}{*}{5} & $C R$ & 0,963 & 0,958 & 0,943 & \\
\hline & $V E$ & 0,745 & 0,719 & 0,74 & \\
\hline & Ket & Sesuai & Sesuai & Sesuai & \\
\hline \multicolumn{2}{|c|}{ Simpulan } & \multicolumn{3}{|c|}{ Reliabilitas Baik } & \\
\hline
\end{tabular}

Keterangan:

komponen 1 : mengajar,

komponen 2 : mendidik, 
komponen 3 : melatih dan mengarahkan, komponen 4 : membimbing, dan komponen 5 : menilai dan mengevaluasi.

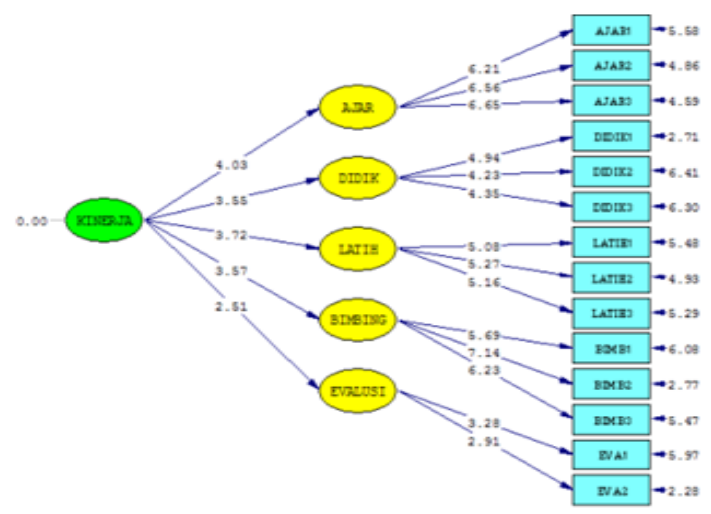

Chi-Square $=71.38$, df $=72, p-$ value $=0.49864$, RUSEA $=0.000$

Gambar 1. Model Pengukuran Kinerja Guru Sekolah Dasar Penilaian diri

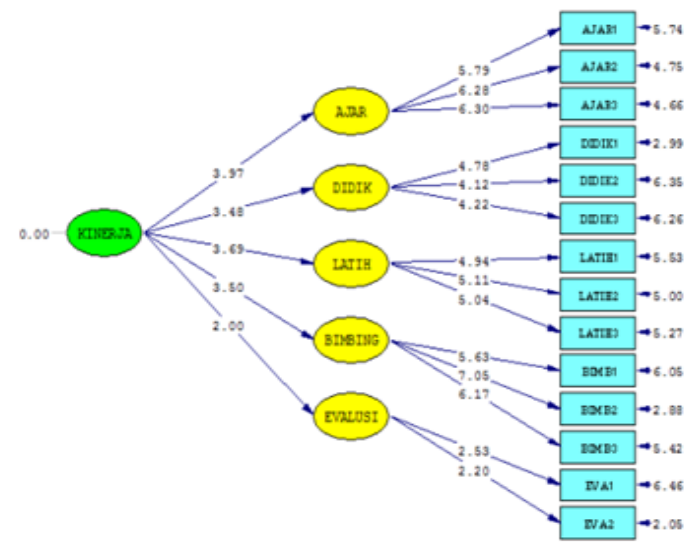

Chi-Square $=72.61$, df $=72$, p-value $=0.45773$, RMSEA $=0.009$

Gambar 2. Model Pengukuran Kinerja Guru Sekolah Dasar Penilaian Sejawat

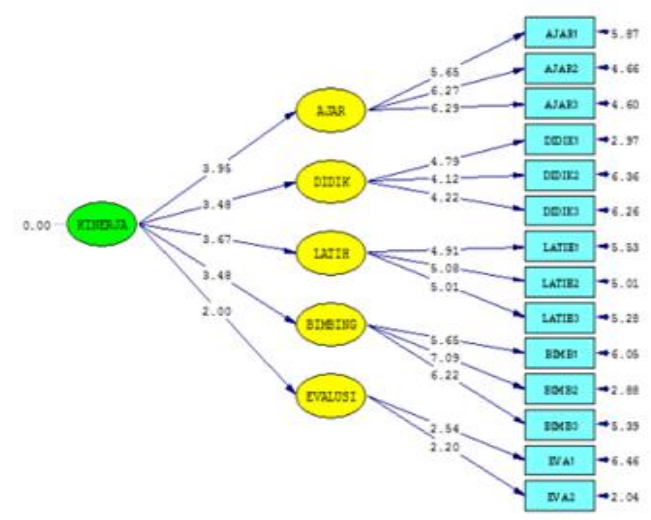

Chi-Square $=72.25, d f=72, p-v a l u e=0.46950$, RUSEA $=0.006$

Gambar 3. Model Pengukuran Penilaian Kinerja Guru (Penilaian Atasan)
Untuk menguji hasil penilaian yang dilakukan penilai yaitu diri sendiri, teman sejawat dan atasan atau kepala sekolah, dilakukan analisis dengan mempergunakan analisis variansi univariate satu jalur, yang dibantu dengan program SPSS.

Tabel 10. Anova Data Penilaian Diri, Sejawat dan Atasan

\begin{tabular}{lccccc}
\hline & $\begin{array}{c}\text { Sum of } \\
\text { Squares }\end{array}$ & $d f$ & $\begin{array}{c}\text { Mean } \\
\text { Square }\end{array}$ & $F$ & Sig. \\
\hline Between Groups & 0,51 & 2 & 0,26 & 0,62 & 0,54 \\
Within Groups & 133,38 & 327 & 0,41 & & \\
\hline Total & 133,89 & 329 & & & \\
\hline
\end{tabular}

Sebagai hasilnya, melalui analisis tersebut $\mathrm{F}$ hitung $=0,624<\mathrm{F}$ tabel, yang dapat dilihat dari Tabel 10, dengan tingkat signifikansi sebesar 0,536, yang berarti lebih besar dari 0,05, menunjukkan bahwa tidak ada perbedaan hasil penilaian yang dilakukan melalui penilaian diri, sejawat dan atasan.

Berdasarkan analisis data tersebut, menunjukkan bahwa instrumen penilaian kinerja guru sekolah dasar, dapat disusun dari model konstruk instrumen penilaian kinerja guru sekolah dasar. Instrumen ini berjumlah 50, yang terbagi dalam 14 indikator, dan membentuk 5 komponen tugas guru, yang dapat digunakan untuk penilaian kinerja guru sekolah dasar. Kelima komponen tugas guru sekolah dasar tersebut merupakan tugas pokok dan fungsi guru sekolah dasar. Artinya guru sekolah dasar dapat dinilai berdasarkan pelaksanaan kerja mereka sesuai tugas pokok dan fungsinya. Hal ini bersesuaian dengan ketentuan perundangan tentang kinerja guru. Guru memiliki tugas pokok dan fungsi untuk melaksanakan pembelajaran dan bimbingan yang terdiri dari pelaksanaan tugas guru dalam mengajar, tugas guru dalam mendidik, tugas guru dalam melatih dan mengarahkan, tugas guru dalam membimbing dan tugas guru dalam menilai dan mengevaluasi.

Berdasarkan ke lima komponen tersebut dapat dijabarkan ke dalam 14 indikator kinerja guru sekolah dasar, yang terdiri dari indikator tugas guru dalam mengajar meliputi: 1) membuat rencana program mengajar, 2) melaksanakan program mengajar, 3) melaksanakan tindak lanjut program mengajar. Artinya kinerja guru dalam mengajar dapat dinilai 
berdasarkan pelaksanaan kerja guru dalam mengajar yang terdiri dari 3 indikator.

Berdasarkan indikator komponen tugas guru dalam mendidik dapat dijabarkan dalam 3 indikator, meliputi: 1) mengembangkan potensi peserta didik, 2) mengembangkan kepribadian peserta didik, 3) melaksanakan penyesuaian penyelengaraan mendidik. Hal ini berarti kinerja guru sekolah dasar dapat dinilai hasil kinerjanya dalam mendidik berdasarkan hasil pelaksanaan kerja guru dalam mendidik dari ke tiga indikator tersebut.

Kinerja guru sekolah dasar dalam melatih dan mengarahkan terdiri dari 3 indikator, yang meliputi: 1) memberikan motivasi belajar, 2) memberikan panduan dalam belajar, 3) membiasakan berperilaku positif. Artinya kinerja guru tersebut dapat dinilai kinerjanya dalam melatih dan mengarahkan berdasarkan hasil pelaksanaan kerja dari ke tiga indikator tersebut.

Kinerja guru sekolah dasar dalam membimbing, terdiri dari 3 indikator. Hal ini menunjukkan bahwa kinerja guru sekolah dasar dalam membimbing dapat dilihat berdasarkan hasil kerja guru sekolah dasar dari ketiga indikator tersebut yaitu 1) membuat rencana program bimbingan, 2) melaksana- kan program bimbingan, 3) melaksanakan tindak lanjut program bimbingan.

Kinerja guru sekolah dasar dalam menilai dan mengevaluasi dapat dilihat berdasarkan hasil kerja guru dalam menilai dan mengevaluasi, yang dapat dijabarkan dalam 2 indikatornya, yaitu: 1) menyusun rencana evaluasi, 2) melaksanakan dan memanfaatakan hasil evaluasi. Artinya kinerja guru sekolah dasar dapat dinilai berdasarkan hasil kerja guru dalam menilai dan mengevaluasi melalui indikatornya dalam wujud menyusun rencana evaluasi, serta melaksanakan dan memanfaatkan hasil evaluasi.

Penggunaan instrumen penilaian kinerja guru sekolah dasar, dapat digunakan untuk mendukung penilaian kinerja yang telah dijalankan. Melalui penilaian kinerja dengan bentuk penilaian diri, penilaian sejawat dan didukung dengan penilaian atasan, yang memiliki substansi yang sama, maka akan dapat menggambarkan keadaan yang komprehensif, dengan demikian hasil penilaian kinerja dapat digunakan untuk melakukan identifikasi kelemahan dan kekurangan dalam cara pandang yang berbeda, tetapi memiliki tujuan hasil yang sama, yaitu kinerja guru sekolah dasar.

Tabel 11. Uji Kriteria GOF pada Uji Second Order Confirmatory 2ndCFA

\begin{tabular}{|c|c|c|c|c|c|c|}
\hline No & Statistik & Kriteria & $\begin{array}{l}\text { Instrumen } \\
\text { Penilaian Diri }\end{array}$ & $\begin{array}{c}\text { Intrumen Penilaian } \\
\text { Sejawat }\end{array}$ & $\begin{array}{c}\text { Instrumen } \\
\text { Penilaian Atasan }\end{array}$ & Simpulan \\
\hline 1 & Chi-Square & $\begin{array}{l}\mathrm{x}^{2}>0,05, \text { model } \\
\text { dinyatakan fit } \\
\text { (Ghozali, 2008: } \\
\text { 30) }\end{array}$ & $\begin{array}{l}\text { Minimum Fit } \\
\text { Function } x^{2}= \\
68,03 \text {; Probabilitas } \\
0,61 ; \text { Normal } \\
\text { Theory WLS } x^{2}= \\
\text { 71,38; Probabilitas } \\
=0,5\end{array}$ & $\begin{array}{l}\text { Minimum Fit } \\
\text { Function } x^{2}= \\
\text { 69,56; Probabilitas } \\
0,56 ; \text { Normal } \\
\text { Theory WLS } x^{2}= \\
\text { 72,61; Probabilitas } \\
=0,46\end{array}$ & $\begin{array}{l}\text { Minimum Fit } \\
\text { Function } x^{2}= \\
69,18 ; \text { Probabilitas } \\
0,57 \text {; Normal } \\
\text { Theory WLS } x^{2}= \\
71,25 ; \text { Probabilitas } \\
=0,47\end{array}$ & $\begin{array}{l}\text { Model Fit ( matrik } \\
\text { imput yang diprediksi } \\
\text { dengan yang } \\
\text { sebenarnya (aktual) } \\
\text { tidak berbeda secara } \\
\text { statistik (Wijanto, } \\
\text { 2007, p.54), (Ghozali, } \\
\text { 2005, p.325). }\end{array}$ \\
\hline 2 & $\begin{array}{l}\text { Root Mean } \\
\text { Square Error of } \\
\text { Approximation } \\
(\mathrm{RMSEA})\end{array}$ & $\begin{array}{l}\text { Terima } \mathrm{H}_{0} \text { bila } \\
\mathrm{RMSE} A<0,05 \\
\text { atau } P \text {-V alue } \geq \\
0,05 \text { (Browne \& } \\
\text { Cudeck, 1993, } \\
\text { Joreskog \& } \\
\text { Sorbom; 1996) }\end{array}$ & $\begin{array}{l}\text { RMSE } A=0,00, \\
\text { jadi RMSE } A<0,05\end{array}$ & $\begin{array}{l}\text { RMSE } A=0,0088, \\
\text { jadi } R M S E A< \\
0,05\end{array}$ & $\mathrm{RMSE} A=0,006$ & $\begin{array}{l}\text { Model Fit (Close Fit) } \\
\text { (RMSEA } \leq 0,05= \\
\text { close fit (Wijanto, } \\
2007 \text {, p.54); RMSE } A \\
\leq 0,05 \text { menandakan } \\
\text { model fit (Wijanto, } \\
\text { 2007, p.54), (Ghozali, } \\
\text { 2005, p.325). }\end{array}$ \\
\hline 3 & $\begin{array}{l}\text { Goodnes of Fit } \\
\text { Index (GFI) }\end{array}$ & $\begin{array}{l}\text { Terima } \mathrm{H}_{0} \text { bila } \\
\text { nilai } G F I \geq 0,9\end{array}$ & $\begin{array}{l}G F I=0,91, G F I> \\
0,9\end{array}$ & $G F I=0,91$ & $G F I=0,91$ & $\begin{array}{l}\text { Model Fit (Nilai GFI } \\
\geq 0,9 \text { merupakan } \\
\text { model fit (Wijanto, } \\
\text { 2007, p.54), (Ghozali, } \\
\text { 2005, p.325). }\end{array}$ \\
\hline
\end{tabular}


Instrumen yang dapat digunakan untuk menilai kinerja guru sekolah dasar berupa instrumen yang disusun berdasarkan komponen tugas pokok dan fungsi guru sekolah dasar. Instrumen yang sesuai adalah instrumen yang memenuhi kualifikasi validitas isi atau content validity, validitas,dan reliabilitas konstruk yang sesuai dengan kriterianya

Didukung data instrumen identitas yang mengidentifikasi tugas administrasi guru, serta beberapa keaktifan yang dilakukan guru, yang dapat disampaikan bahwa untuk administrasi guru telah dilaksanakan dengan baik, yang dapat ditunjukkan berdasarkan penilaian diri, sejawat dan atasan.

Berdasarkan analisis tersebut, dapat dikatakan bahwa penilaian kinerja guru sekolah dasar, seharusnya mempergunakan penilaian diri, penilaian sejawat dan penilaian atasan. Ketiga penilaian tersebut dipadukan, sehingga mampu menghasilkan nilai yang lebih objektif. Jika dilihat berdasarkan hasil fit model, maka penilaian kinerja akan mempergunakan bentuk penilaian yang berbeda-beda, seperti untuk penilaian tugas guru dalam mengajar, disarankan untuk mempergunakan instrumen penilaian atasan. Hal ini dapat dipahami berkaitan dengan penilaian tugas guru dalam mengajar sering dilakukan oleh kepala sekolah melalui observasi kelas. Jadi kepala sekolah sangat memahami pekerjaan guru yang dinilai, demikian halnya penilaian tugas guru dalam melatih dan mengarahkan.

Penilaian kinerja guru dalam mendidik dan membimbing, sangat tepat jika mempergunakan instrumen penilaian diri, hal ini disebabkan karena tugas guru sekolah dasar, dalam mendidik dan membimbing lebih memiliki sifat bukan administratif, tetapi lebih pada pendekatan kepada siswa.

Penilaian kinerja guru dalam menilai dan mengevaluasi, sangat tepat mempergunakan instrumen penilaian sejawat, hal ini dikarenakan, sejawat, lebih memahami dalam wujud dari hasil kerja guru dalam pelaksanaan tugas menilai dan mengevaluasi. Hal ini disebabkan tugas guru dalam menilai dan mengevaluasi lebih cenderung melibatkan kerja sama dalam tim atau kelomok, seperti dalam membuat instrumen yang akan di- gunakan untuk pelaksanaan ujian sekolah, tengah semester dan semester.

Berdasarkan nilai validitas dan reliabilitas masing-masing instrumen yang cukup baik. Ditunjang dengan fit model yang cukup baik secara keseluruhan, menunjukkan bahwa instrumen penilaian kinerja guru dapat digunakan secara menyeluruh. Hal ini berlaku untuk ketiganya, yaitu kinerja guru untuk penilaian diri, penilaian dari teman sejawat dan penilaian atasan yaitu kepala sekolah.

\section{Simpulan}

Berdasarkan penelitian dan pengembangan terhadap Instrumen Penilaian kinerja Guru sekolah dasar dapat disimpulkan sebagai berikut:

Komponen tugas guru sekolah dasar yang mencakup mendidik, mengajar, melatih dan mengarahkan, membimbing, serta menilai dan mengevaluasi signifikan dan relevan untuk mengukur kinerja guru. Data yang dihasilkan dari pengukuran kinerja guru dari penilaian diri, sejawat dan atasan tersebut tidak memiliki perbedaan yang berarti.

Tiap indikator dalam tiap komponen tugas guru tersebut relevan dan signifikan, sehingga dapat dijelaskan sebagai berikut: Indikator tugas guru sekolah dasar dalam mengajar terdiri dari 1) membuat rencana program mengajar, 2) melaksanakan program mengajar, 3) melaksanakan tindak lanjut program mengajar.

Indikator tugas guru sekolah dasar dalam mendidik terdiri dari: (1) mengembangkan potensi peserta didik, (2) mengembangkan kepribadian peserta didik, (3) melaksanakan penyesuaian penyelengaraan mendidik.

Indikator tugas guru sekolah dasar dalam melatih dan mengarahkan terdiri dari (1) memberikan motivasi belajar, (2) memberikan panduan dalam belajar, (3) membiasakan berperilaku positif.

Indikator tugas guru sekolah dasar dalam membimbing terdiri dari: (1) membuat rencana program bimbingan, (2) melaksanakan program bimbingan, dan (3) melaksanakan tindak lanjut program bimbingan.

Indikator tugas guru sekolah dasar dalam menilai dan mengevaluasi terdiri dari (1) 
menyusun rencana evaluasi, serta (2) melaksanakan dan memanfaatakan hasil evaluasi.

Instrumen yang dapat digunakan untuk menilai kinerja guru sekolah dasar berupa instrumen yang disusun berdasarkan komponen tugas pokok dan fungsi guru sekolah dasar. Instrumen yang sesuai adalah instrumen yang memiliki kualifikasi validitas isi atau content validity, validitas, dan reliabilitas konstruk yang sesuai dengan kriterianya.

Dapat disarankan untuk pemanfaatan produk sebagai berikut: (1) Instrumen penilaian kinerja guru sekolah dasar, akan lebih baik jika mempergunakan instrumen penilaian diri, instrumen penilaian sejawat dan instrumen penilaian atasan. Ketiga instrumen tersebut dipadukan, sehingga mampu menghasilkan nilai yang lebih obyektif. (2) Berdasarkan fit model terbaik, maka instrumen penilaian kinerja guru sekolah dasar akan mempergunakan bentuk instrumen yang berbeda-beda, seperti (a) instrumen tugas guru dalam mengajar, dan melatih disarankan untuk mempergunakan instrumen penilaian atasan; (b) instrumen penilaian kinerja guru dalam mendidik dan membimbing, sangat tepat jika mempergunakan instrumen penilaian diri, dan (c) instrumen penilaian kinerja guru dalam menilai dan mengevaluasi, sangat tepat mempergunakan intrumen penilaian sejawat. (3) Berdasarkan nilai validitas dan reliabilitas masing-masing instrumen yang cukup baik. Ditunjang dengan fit model yang cukup baik secara keseluruhan, menunjukkan instrumen penilaian kinerja guru dapat digunakan secara menyeluruh. Hal ini berlaku untuk ketiganya, yaitu kinerja guru untuk instrumen kinerja dari penilaian diri, instrumen penilaian kinerja dari penilaian teman sejawat dan instrumen kinerja dari penilaian atasan yaitu kepala sekolah. 4) Instrumen penilaian kinerja guru sekolah dasar dapat dikembangkan lebih lanjut agar lebih sempurna, hal ini karena keterbatasan-keterbatasan yang ada, seperti pembatasan dalam dimensi penilaian, mapun subyek coba.

\section{Daftar Pustaka}

Anderson, D \& Carl Brydges, B, (2011). Professional Teaching Dispositions For
Elementary Versus Middle/Secondary: Testing The Generalizability of Finding From Rubric Assessment Data To Identify And Improve Performance of Struggling And High Risk Teacher Candidates. (Electronic Version) International Journal of Arts \& Sciences. 4(11): 253-268.

Amin, H. U.\& Khan A. R. (2009). Acquiring Knowledge for Evaluation of Teachers' Performance in Higher Education using a Questionnaire. (IJCSIS) International Journal of Computer Science and Information Security, Vol. 2, No. 1.

Azwar, S., (2010). Penyusunan Skala Psikologi Edisi 1. Yogyakarta: Pustaka Pelajar. (2013). Penyusunan Skala Psikologi Edisi 2, Yogyakarta: Pustaka Pelajar.

Basuki, H., (2004). Analisis Faktor Konfirmatori (Confirmatory Factor Analysis) dalam Materi Pelatihan SEM (Structural Equation Modeling) Angkatan IV. Surabaya: Lembaga Penelitian Universitas Airlangga Surabaya.

Berk, R. A, \& Hopkins, J. (2005). Survey of 12 Strategies to Measure Teaching Effectiveness, International Journal of Teaching and Learning in Higher Education, http://www.isetl.org/ijtlhe/ 2005, Volume 17, Number 1, 48-62, ISSN 18129129.

Borg,W.R.,\& Gall,M.D. (1983). Education research: an introduction. New York: Longman inc.

Borg,W.R.,\& Gall,M.D., Gall, J.P.(2003). Education research: an introduction. New York: San Francisco.

Budiyono, (2009). Bahan Kuliah Statistik Multivariat. Yogyakarta: Program Pasca Sarjana UNY.

Coakes, S.J. \& Steed. D. (1996). SPSS for Window: analysis without anguish. Melbourne: Jacaranda Wiley LTD.

Dharma, S. (2011). Manajemen Kinerja. Yogyakarta: Pustaka Pelajar.

Pengembangan Instrumen Penilaian Kinerja Guru - 303

Hesti Sadtyadi, Badrun Kartowagiran 
Ghozali, I. (2008). Structural equation modelling: teori, konsep \& aplikeasi program liserel. Semarang: Badan Penerbit Undip.

Hair,J.E, Jr. et al. (2006). Multivariate data analysis. (6 ed). Upper Saddle River, New Jersey: Prentice-Hall, Inc.

Mohamad, E., (2012), Evaluasi Kinerja Guru SMPN di Kota Gorontalo. Disertasi, Universitas Negeri Jakarta

Nuland, S.V. (2009). Teachers Codes; learning from experience, New York: International for Institute for educational planing.

Nunnally, J. C. (1981). Psychometric Theory (2nd Ed). New York: McGraw-Hill.

Rivai, V., et al. (2008). Performance appraisal; system yang tepat untuk menilai kinerja karyawan dan meningkatkan daya saing perusabaan. Jakarta: PT Raja Grafindo Persada.

Saud,U.S.,. (2010). Pengembangan Profesi Guru. Bandung: Alfabeta.

Sudarwan, D. (2002). Inovasi Pendidikan dalam upaya Peningkatan profesionalisme Tenaga Kependidikan. Bandung: Pustaka Setia.

Suryadarma, D., Suryahadi, A.,\& Sumarto,S., (2005). Penentu Kinerja Murid Sekolah Da- sar di Indonesia. Jakarta: Semeru, Yertas Verja (World Bank).

Supardi, (2013). Kinerja Guru. Jakarta: Raja Grafindo Persada.

Tsang, T.H.Y. (2003). Using Standardized Performance Observations And Interviews To Asess The Impact of Teacher Education, Dissertation. In the Graduate College The University of Arizona. (Versi Electronik by ProQuest Information and Learning Company).

Wagiran (2010), Determinan Kinerja Guru SMK Kelompok Keablian Teknologi dan Industri Bidang keablian Teknik Mesin. Disertasi. Yogyakarta: Pasca Sarjana Universitas Negeri Yogyakarta.

Wibowo, A., (2004). SEM Structural Equation Modeling (Pengantar Analisis Faktor Ekesploratory dan Analisis Faktor Confirmatory). Surabaya: Lembaga Penelitian Universitas Airlangga.

Wijanto,S.,H., (2008). Structural Equation Modeling dengan Lisrel 8.8. Yogyakarta: Graha Ilmu.

Yamin, M., \& Maisah. (2010). Standardisasi Kinerja Guru. Jakarta: Gaung Persada. 